\title{
PROBLEMS OF OPERATION OF MARGINAL PRODUCERS WITH ANNULAR GAS SHOWINGS
}
• • устышев, • • озлов
лимулин , .
ирьянов

A. V. Kustyhev, A. S. Kozlov, M. Ya. Kalimulina, V. V. Kiryanov

юменский индустри льный университет, г.юмень

лючевые слов : скв жин ; межколонные г зопроявления; эксплу т ция; межкколонное простр нство; ф кельн я, 3 д вочн я ивыкидн ялинии; $з$ движк ; горелк

Key words: well; annular gas showings; operation; annular space; flare line; kill and flow line, valve; burner

ефтег зоконденс тные месторождения ибири и льнего осток $\mathrm{x}$ р ктеризуются суровыми клим тическими условиями, недост точной изученностью геологического строения, плохой тр нспортной р звязкой. урение скв жин в этих условиях з труднено, эксплу т ция требует повышенного вним ния. ередко эти процессы связ ны с возникновением межколонных г зопроявлений. ксплу т ция скв жин с н личием межколонных д влений пр вил ми безоп сности з прещен без 
р зр ботки специ льных компенс ционных мероприятий, н пр вленных н обеспечение н дежности конструкций скв жин, их устьевых обвязок и н обеспечение повышенных мер пож рной и противофонт нной безоп сности $[1,2]$.

этих условиях необходим технология безоп сной эксплу т ции скв жин, имеющих межколонные д вления. езоп сность эксплу т ции, помимо н дежной конструкции с мой скв жины, т кже определяется н дежностью устьевых обвязок этих скв жин [3].

ще всего при эксплу т ции скв жин с межколонными г зопроявлениями применяется устьев я обвязк . пример, н полярном месторождении и ряде других месторождений $\mathrm{p}$ йнего евер используется обвязк , включ ющ я колонную головку с з движкой, перекрыв ющей межколонное простр нство, и дополнительный ф кельный отвод [4].

едост тком д нной обвязки является необходимость строительств отвод, не предусмотренного проектно-сметной документ цией.

ногд используют устьевую обвязку, т кую к к н ов ненковском месторождении, включ ющую колонную головку с з движкой, перекрыв ющей межколонное простр нство, и дополнительный ф кельный отвод [5].

едост тком является то, что при ее ре лиз ции необходимы зн чительные к пит льные вложения, связ нные со строительством дополнительного ф кельного отвод , и невозможность в случ е необходимости 3 к ч ть в межколонное простр нство герметизирующую композицию для ликвид ции межколонных г зопроявлений.

ем не менее при использов нии этих обвязок реш ется основн я 3 д ч возможность эксплу т ции г зопроявляющих скв жин 3 счет выпуск $Г$ г из межколонного простр нств и снижения величины межколонного д вления в скв жине, которое может привести к осложнениям, в риям и д же к возникновению открытого г зового фонт н и пож р $[6,7,8]$.

дн ко при этом ост ется нерешенной друг я нем лов жн яз д ч - возможность ликвид ции межколонных г зопроявлений путем з к чив ния в межколонное простр нство скв жины герметизирующей композиции. ля решения этой з д чи необходимо р зр бот ть новую схему обвязки г зопроявляющих скв жин нез висимо от количеств секций колонных головок и соответственно числ межколонных простр нств.

нную 3 д чу можно решить путем присоединения к к ждой з движке, перекрыв ющей соответствующее межколонное простр нство скв жины, п трубков, p сположенных в горизонт льной плоскости, с р змещенным между ними соединительным п трубком, причем к верхнему угольнику присоединен дополнительн я межколонн я 3 движк, к которой присоединен предохр нительный кл п н, к которому в свою очередь присоединен дополнительн я ф кельн я линия с концевой 3 движкой, н торц х ф кельных линий р змешены горелки.

рисунке проиллюстриров н $\mathrm{p}$ зр бот нн я втор ми схем устьевой обвязки низкодебитной г зоконденс тной скв жины с межколонными г зопроявлениями реднеботуобинского месторождения кутии, относящегося $\mathrm{K}$ месторождениям р йнего евер [9].

стьев я обвязк включ ет скв жину с устьем 1 , р сположенным в ш хтном колодце 2. устье 1 р змещен многосекционн я колонн я головк 3 , к жд я секция которой сн бжен 3 движкой 4, перекрыв ющей соответствующее межколонное простр нство скв жины, нижнее или верхнее.

колонной головке 3 р змещен трубн я головк 5 , сн бженн я н противоположных сторон х выкидным 6 и $з$ д вочным 7 отвод ми. выкидном отводе 6 р 3мещены $з$ трубные 3 движки 8 и 9, н 3 трубном отводе $7-3$ трубные 3 движки 10 и 11. ежду з движк ми 8 и 9 р змещен инструмент льный фл нец 12, между 3 движк ми 10 и 11 - тройник 13 , обеспечив ющий сообщение с межколонными простр нств ми скв жины.

трубной головке 5 р змещен фонт нн я елк тройникового тип, ствол которой выполнен из центр льной 14 и стволовой 15 з движек, р сположенных друг н д другом, нижнего 16 и верхнего 17 тройников и буферной з движки 18. 
верхнему тройнику 17 присоединен р боч я струн 19 с двумя струнными 3 движк ми 20,21 и р сположенным между ними инструмент льным фл нцем 22.

нижнему тройнику 16 присоединен резервн я струн 23 с двумя струнными 3 движк ми 24, 25 и р сположенным между ними инструмент льным фл нцем 26.

боч я струн 19 посредством тройник 27 соединен с выкидным отводом 6 трубной головки 5, обр зуя выкидную линию 28.

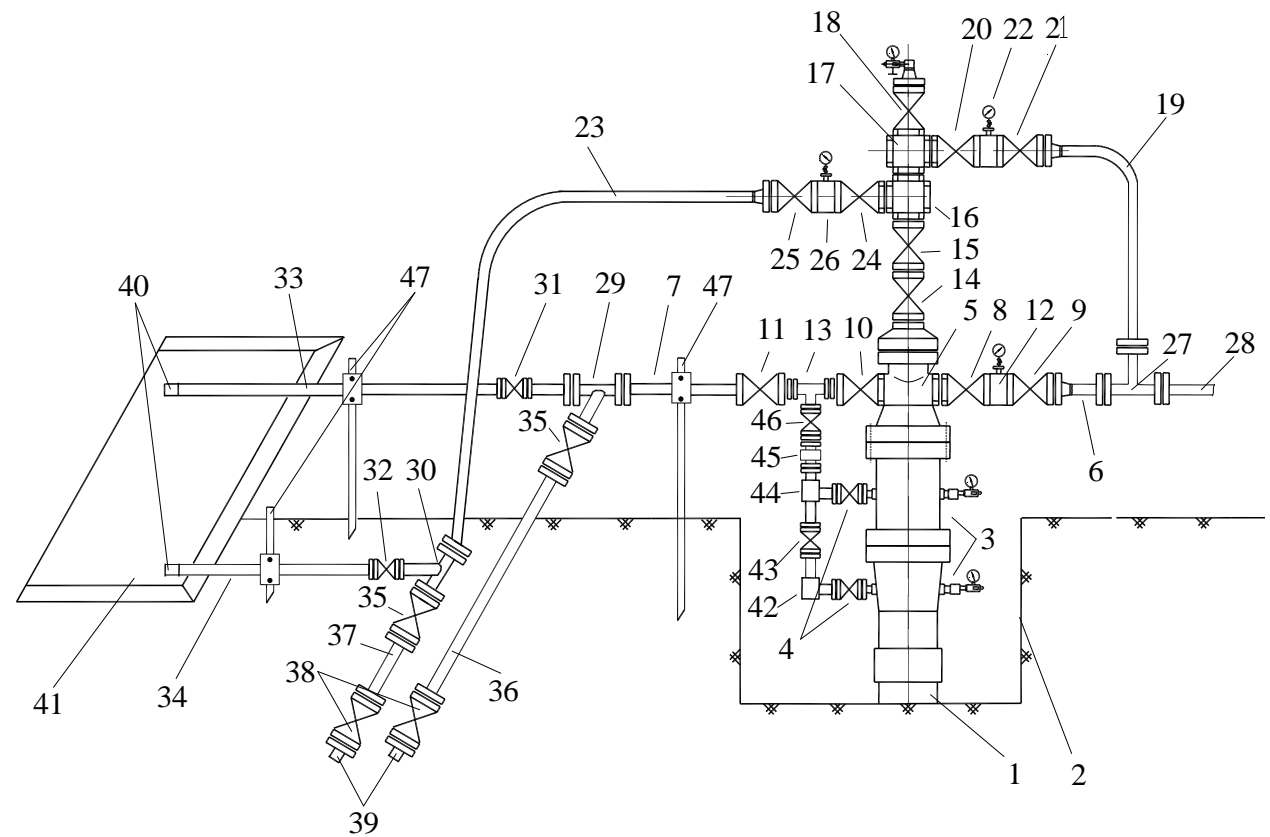

исунок. хем устьевой обвязки низкодебитной г зоконденс тной скв жины слмжколонными 2 зопроявлениями, оборудов нной двухсекционной колонной головкой: 1 -устье; $2-ш$ хт ; 3 - двухсекционн я колонн яголовк;4-з движк н межколонном простр нстве; 5 - трубн я головк ; 6-выкидной отвод; 7-з д вочный отвод; 8, 9, 10, 11 3 движки н з трубном простр нстве; 12, 22, 26 - инструмент льные фл нцы; 13, 27, 29, 30, 44 - тройники; 14 - центр льн яз движк; 15 - стволов яз движк;16-нижний тройник; 17 - верхний тройник; 18 - буферн я з движк ; 19 -р боч я струн; 20, 21, 24, 25 - струнные з движк ; 28-выкидн я линия; 31, 32, 35 - отсек ющие з движки; 33, 34 - ф кельные линии; 36, 37 - з д вочные линии; 38 - концев я отсек юш яз движк; 39 - быстрор збемное соединение; 40 - горелк ; 41 - мб р; 42 - угольник; 43, 46-р зделительные межколонные з движки; 45 - предохр нительный кл $n$ н; 47 -якорь

концевых уч стк х резервной струны 23 и з д вочного отвод 7 трубной головки 5 р змещены тройники 29 и 30 , к одному ответвлению которых присоединен через 3 движку 31 или 32 ф кельн я линия 33 или 34, к другому, через з движку 35 или 36, 3 д вочн я линия 36 или 37. торц х к ждой з д вочной линии 36 и 37 р змещены концевые отсек ющие 3 движки 38 с быстрор зъемными соединениями 39, н торц х ф кельных линий 33 или 34 - горелки 40, выведенные в мб р 41.

нижней 3 движке 4, перекрыв ющей нижнее межколонное простр нство скв жины, присоединен угольник 42, к вертик льному концу которого присоединен нижняя р зделительн я $з$ движк 43, котор я присоединен к тройнику 44 , один конец которого соединен с верхней $з$ движкой 4, перекрыв ющей верхнее межколонное простр нство скв жины, второй конец - с предохр нительным кл п ном 45, н котором р змещен верхняя р зделительн я 3 движк 46, котор я в свою очередь присоединен к тройнику 13, р сположенном н 3 д вочном отводе 7 между з трубными 3 движк ми 10 и 11. 
зопроявляющ я скв жин р бот ет следующим обр зом. процессе эксплу т ции г з из продуктивного пл ст по стволу фонт нной елки через открытые центр льную 14 и стволовую 15 з движки, по ее р бочей струне 19 и выкидной линии 28 поступ ет в г зосборный коллектор и д лее н уст новку комплексной подготовки г 3 .

ри появлении в процессе эксплу т ции межколонных г зопроявлений г 3, ск плив ющийся в межколонном простр нстве скв жины, через открытые $з$ движки 4, 43 u $46, \mathrm{p}$ змещенные в ш хтном колодце 2 скв жины, через открывшийся предохр нительный кл п н 45, который открыв ется при превышении величины межколонного д вления выше н строечной величины кл п н, p вного предельно допустимой величине межколонного д вления д нной скв жины, поступ ет через тройник 13 в 3 д вочный отвод 7 , д лее через тройник 29, открытую з движку 31 поступ ет н ф кельную линию 33 и сгор ет н горелке 40 в мб ре 41.

случ е в рийного увеличения р сход г з из межколонного простр нств скв жины выше величины н строечного дебит предохр нительный кл п н 45 з кроется, прекр тив поступление г 3 из межколонных простр нств в ф кельную линию 33.

ри д льнейшем увеличении р сход г 3 из межколонного простр нств скв жины через 3 д вочную линию 36, соединенную с $з$ д вочным отводом 7 трубной головки 5 , можно провести в рийное 3 к чив ние герметизирующей композиции в межколонное простр нство скв жины, предв рительно перекрыв отсек ющую з движку 31 н ф кельной линии 33 путем подсоединения к быстрор зъемному соединению 39 н сосного грег т для под чи через концевую отсек ющую з движку 38 герметизирующей композиции и прекр щения г зопроявлений.

случ е глушения скв жины или ее промывки через з д вочную линию 37 , соединенную с резервной струной 23, предв рительно 3 крыв 3 движку 32 н ф кельной линии 34, можно в трубное простр нство скв жины з к ч ть 3 д вочную или промывочную жидкость, котор я через з трубное простр нство скв жины, з д вочный отвод 7, открытую 3 движку 31 при з крытой з движке 33 поступит в ф кельную линию 33 и в мб р 41 или сборную емкость.

римером ре лиз ции предложенного втор ми технического решения является двухсекционн я г зоконденс тн я скв жин реднеботуобинского месторождения.

стьев я обвязк г зоконденс тной скв жины включ ет двухсекционную колонную головку 2-350-168x245, сн бженную з движк ми $60 \times 35$, перекрыв ющими межколонное простр нство скв жины, трубную головку $100 x 35$, сн бженную 3 движк ми 100х35, перекрыв ющими з трубное простр нство, фонт нную елку

100x35. онт нн я елк тройникового тип содержит центр льную, стволовую и буферную з движки 100x35, нижний и верхний тройники, р бочую и резервную струны условным диметром 100 мм. боч я струн соединен с выкидным отводом трубной головки и обр зует выкидную линию условным диметром 100 мм. концевых уч стк х резервной струны и 3 д вочного отвод трубной головки р змещены тройники, к одному ответвлению которых присоединен ф кельн я линия условным ди метром 100 мм, к другому - 3 д вочн я линия условным диметром 100 мм. торц х 3 д вочных линий р змещены концевые отсек ющие 3 движки $100 \times 35$ с быстрор зъемными соединениями -100, н торц х ф кельных линии - горелки.

нижней $з$ движке, перекрыв ющей нижнее межколонное простр нство скв жины, присоединен угольник 60х60, р зделительн я з движк $60 x 35$, р змещенн я в вертик льной плоскости, тройник 60х60х60, присоединенный к з движке, перекрыв ющей верхнее межколонное простр нство, р зделительн я 3 движк 60х35, предохр нительный кл п н $\quad-14$, который в свою очередь присоединен к 3 д вочному отводу условным ди метром 100 мм.

нн я обвязк позволяет осуществлять безоп сную эксплу т цию низкодебитных г зоконденс тных скв жин с межколонными г зопроявлениями 3 счет безоп сного выпуск г з из межколонных простр нств скв жины с соблюдением безоп сности проведения р бот по 3 к чив нию герметизирующих композиций при миним льных 3 тр т х н ее обустройство.

ким обр зом, $\mathrm{p}$ зр бот нные устьевые обвязки г зопроявляющих скв жин обеспечив ют возможность выпуск г з из их межколонных простр нств и сжиг ния 
его в обв лов нном мб ре, обеспечив ют возможность 3 к чив ния в межколонное простр нство герметизирующих композиций для ликвид ции межколонных г зопроявлений, т кже - созд ния циркуляции 3 д вочной жидкости между трубным и з трубным простр нств ми с использов нием одного и того же трубопровод при глушении скв жин с межколонными г зопроявлениями.

писок литер туры

1. устышев . . ксплу т ция скв жин н месторождениях п дной ибири. - юмень: ектор ук, 2002. -168 с.

2. редотвр щение и ликвид ция г зопроявлений и открытых фонт нов при ремонте скв жин в экстрем льных условиях р йнего евер / . . б ев, . . устышев, . . озуля, . . ейхм н. - ..

3. устышев . ., г нов . ., ур влев . . ценк риск при ремонте нефтяных и г зовых скв жин // езоп сность труд в промышленности. - 2013. - № 9. - . 76-80.

4. т. 44143 . 21 43/25. стройство для эксплу т ции г зовых скв жин с межколонными г зопроявлениями / . . толь, . . у устышев, . . ыб лченко и др. ( ). - № 2004128574, з яв. 27.09.04; опубл. 27.02.05, бюл. № 6.

5. т. 111578 . 21 43/12. устов я обвязк г зовых скв жин с межколонными г зопроявлениями / . . емков, . . устышев, . . . толь и др. ( ). - № 2011134831, з яв. 19.08.11; опубл. 20.12.11, бюл. № 35.

6. оинс . . редотвр щение выбросов: ер. с нгл./ . . оинс, . еффилд. - .: едр , 1987. - 288 с.

7. устышев . . ложные ремонты г зовых скв жин н месторождениях п дной ибири. - .: « зпром экспо», 2010. -212 с

8. екетов . . ехнология ди гностики герметичности з колонной крепи скв жин н месторождениях и подземных хр нилищ х г 3 // орный информ ционно- н литический бюллетень. - 2003. - № 6. - . 38-42.

9. енн . . е етоды ди гностики и ликвид ции межколонных флюидопроявлений при строительстве скв жин н месторождениях и : втореф. ...дис. к. т. н.: 05.15.10. - щищен 20.05.99. - т врополь, 1999. - 19 с.

10. т. 143089 . бвязк высокодебитной нефтег зоконденс тной скв жины с межколонными г зопроявлениями / . . устышев, . . озлов, . . устышев, . . ирьянов, . . лимулин . - № 2014105118, 3 яв. 12.02.24; опубл. 10.07.14, бюл. № 19 .

\section{ведения об втор $x$}

устышев лекс ндр сильевич, Ә. т. н., профессор к федры « урение нефтяных и г зовых скв жин», юменский индустри льный уни верситет, г.юмень, тел. 8(3452)200989, е-таil: kustishev@tngg.info

озлов лексей ергеевич, гл вный геолог

" - 3», еспублик $x$ (кутия),

2. ирныци

лимулин эглем нв ровн, специ лист $2 \kappa$ тегории, юменский индустри льный университет, г. юмень

ирвянов л димир сильевич, ведущий инженер - "зпром добыч м-

бург», , г. - ренгой

\section{Information about the authors}

Kustyshev A. V., Doctor of Engineering, professor of the chair "Drilling of oil and gas wells», Industrial University of Tyumen, phone: 8(3452)200989,e-mail: kustishev@tngg.info

Kozlov A. S., chief geologist of OJSC «ALROSAGas», the Republic of Sakha/Yakutiya, the town of Mirny

Kalimulina M. Ya., category II specialist of the chair "Drilling of oil and gas wells», Industrial University of Tyumen

Kiryanov $\boldsymbol{V} . \boldsymbol{V}$., leading engineer, $L L C \ll G a$ sprom Dobycha, Yamburg», Yamalo-Nenets Autonomous Okrug, Novy Urengoy 